\title{
Penge og ånd
}

\section{Flensborg-købmanden Hans Feddersens vej til brødremenigheden}

\section{af Lars N.Henningsen}

Om Flensborg-købmændene sagde man i ældre tid, at de kun var optaget af én ting: penge. Dette er dog ikke hele sandheden. Pietismen og senere brødremenighedens tanker vandt fodfæste $\mathrm{i}$ byen, og måske fik handelslivet ny kraft gennem denne inspiration. I artiklen her fortælles om Hans Feddersen (1739-1813). Han hørte til Flensborgs handelselite, men endte sit liv som »missionsmand « - åndeligt set ret langt fra udgangspunktet.

I begravelsesregistret for Løjt sogn ved Aabenraa årgang 1813 står følgende at læse: "Død den 8.oktober 1813 Hans Feddersen, Bohlsmand i Kirkebye, var en Søn af den kongel. Commerz. Assessor Martin Feddersen og Adelheit fød Løit i Flensborg, gift med Mergreth Sophie fød Carstens af Husum, han efterlader denne sin Hustrue og 2de Børnebørn, navnl. Mergreth Sophie og Ellen af hans afdøde Datter Dorothea, som var gift med Nis Holmann. Alder 74 Aar 8 Maaneder «'.

Dette virker egentlig ikke særlig påfaldende. En gårdmand er død i høj alder efterladende hustru, børnebørn og en svigersøn blandt sognets kendte familier. Og dog - man læser også, at afdøde var født i Flensborg, hvor faderen tilsyneladende var noget ud over det almindelige, "kommerceassessor«. Nysgerrigheden er vakt, og går man sagen efter, viser det sig, at Hans Feddersen faktisk var alt andet end en typisk løjting. Den gamle mand havde haft en ret usædvanlig karriere. Han var født ind i et af Flensborgs rigeste købmandshuse og sad gennem en årræke $i$ firmaets chefstol - indtil han fik nok af denne pengeverden. Han opgav forretningen - blev landmand - og en ivrig forkæmper for herrnhuter-brødrenes sag. Han startede med at "jagte penge«, og sluttede med at njagte sjæle $\ll$.

\section{Familien Feddersen}

Feddersen-familien hørte i det meste af 1700-tallet til Flensborgs absolutte handelselite. Stamfaderen Nis Feddersen var født 1631 i Sillerup i Store Vi sogn vest for Flensborg. Som mange andre energiske unge fra landet drømte han om at komme frem $i$ verden uden for bondestanden, og da Karl Gustav- 
krigen i 1659 havde efterladt hjemegnen fattig og plyndret, drog han til egne, som var skånet af krigen. I 1664 tog han borgerskab i Rudkøbing som kræmmer. Heldet fulgte ham. Han handlede med vin og fremmed øl, fik skibe i søen, blev rådmand, erhvervede adskillige huse i byen, og da han døde 1691 var det som byens største skatteyder ${ }^{2}$.

Af børnene vendte sønnen Peter Feddersen tilbage til familiens hjemstavn. Han var født i Rudkøbing 1664. 13 år gammel blev han sendt til Flensborg for at lære tysk og finde en levevej som købmand. Enken efter den ansete købmand og silkehandler Heinrich Meincke optog drengen i sit hus, og han besøgte byens skoler et år. Derefter samlede han gennem 7 år erfaring som lærling i fruens betydelige købmands- og manufakturhandel. Enkefru Lucia Meincke var tilfreds, og den unge mand fortsatte endnu to år i forretningen som købmandssvend. Derpå begyndte han at lægge grunden til en selvstændig forretning. Talrige rejser til Hamborg, Lübeck, København, Norge og Holland knyttede kontakter til leverandører og kunder, således at han i 1692 kunne slå fast rod i Flensborg. Den 3.oktober 1692 stod brylluppet med Lucia Sühling, datter af Flensborg-købmanden Detlef Sühling. Forretningen udviklede sig, først gennem 16 år i kompagniskab med konens svoger, rådmand og silkehandler Iver Petersen ${ }^{3}$.

Peter Feddersens virke blev frugtbart - 13 sønner og 5 døtre voksede op $i$ købmandsgården; og da han døde 1732, var familien godt på vej til at spille en fremtrædende rolle $i$ flere grene af byens handelsliv. 5 af sønnerne blev købmænd i hjembyen, men kun de tre oplevede en længere karriere, og det var for alle tre i faderens branche, altså som tekstilkøbmænd.

Sønnen Martin Feddersen (1706-74) oprettede selvstændig forretning 1732 i ejendommen Holm 7 - i denne ejendom indrettedes 1852 den danske appellationsret, og 1883 flyttede byens rådhus ind her. Broderen Friederich (1703-75) åbnede sin forretning $\mathrm{i}$ huset Holm 70-72 og Johann Gerhard (1712-87) fulgte efter med en selvstændig en-gros handel med lærred og uldvarer i 1745 på adressen Holm 41. Dog holdt han ikke åben butik således som brødrene. De tre brødre var alle placeret på det mest forgyldte strøg af Flensborgs hovedgade 4 .

Mange år senere, i 1777, skrev Johann Gerhard sin selvbiografi, og den giver et fint billede af en storkøbmands uddannelse i de dage. Oprindelig ville forældrene holde Johann Gerhard til bogen, og han nåede også 3. klasse i latinskolen. Men en rejse til Sjælland, Falster, Lolland og København i 1728 for at inkassere store beløb for faderen gav ham en sådan lyst til rejse- og købmandslivet, at kursen blev lagt om: wherefter blev købmandskabet stedse mit hoved-temperament«, skrev han. I 1729 rejste brødrene Friederich og Johann Gerhard sammen til Amsterdam, hvor broderen Peter da opholdt sig. 


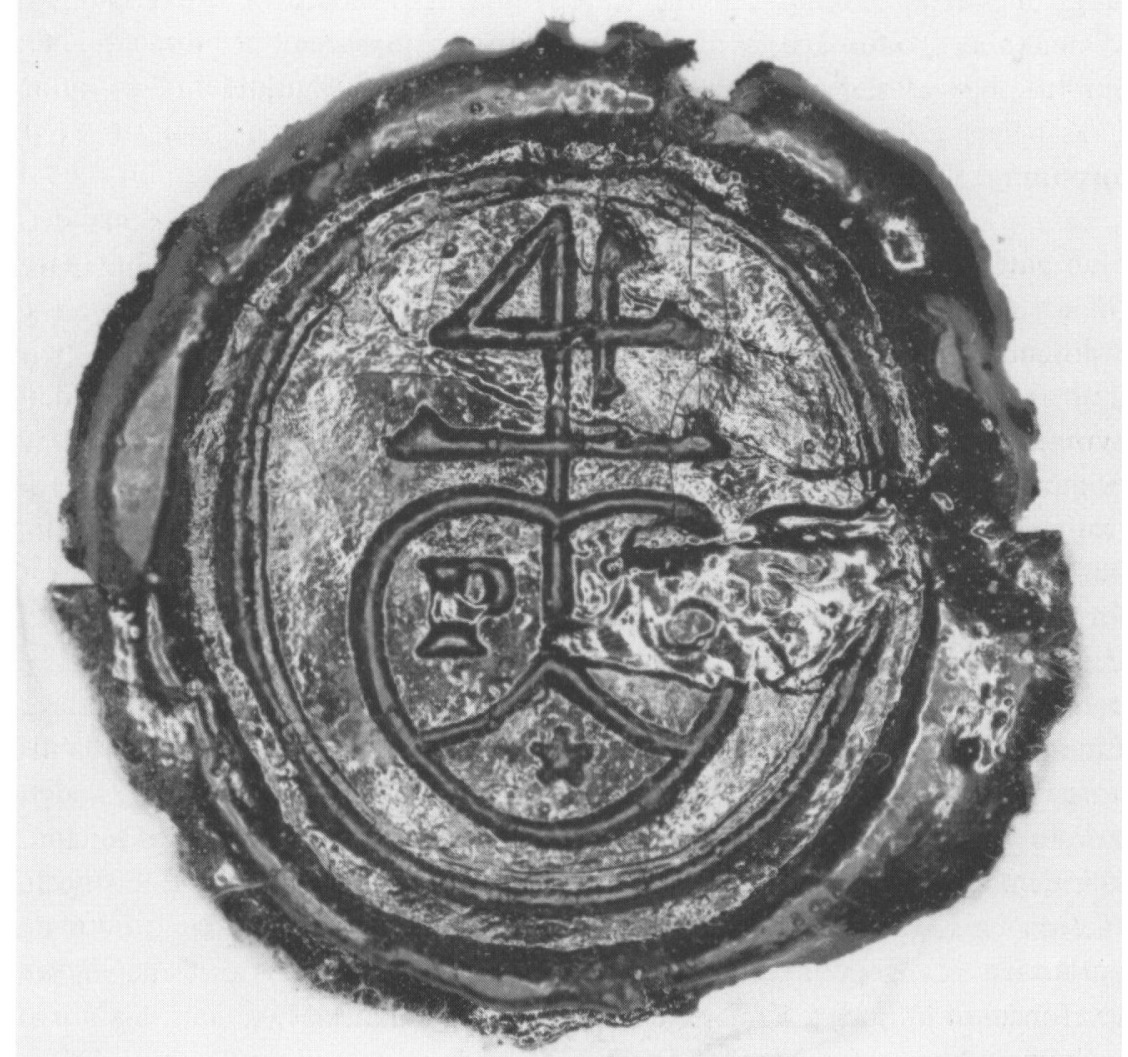

Kobmand Peter Feddersen i Flenshorg havde fine kunder i sin forretning - bl.a. hertuginde Christiana pd Glücksborg. I àrene fra 1710 til 1721 leverede han varer for mere end 3.300 mark til hoffet tekstiler, stromper, fiskeben, knapper, kamme, the, snustobak m.v. Men det var svart at vriste kontanter ud af den slunkne hertugelige pengekasse. Peter Feddersens segl, som er gengivet her, findes på et af mange rykkerbreve til hertuginde Christiana. Seglet barer et bomarke og kobmandens initialer $P$ og $F$ ( sidstnavinte odelagt).

Rigsarkivet. Glücksborg 90 II. Rigsarkivet foto.

Her tjente Johann Gerhard en kort tid hos en urtekræmmer. Et par år senere foretog han den helt store rejse. I Amsterdam studerede han livet på Børsen, handel og fabrikker, i Bordeaux besøgtes et sukkerraffinaderi, flere handelshuse og de store vinhuse, som havde betydelige leverancer til Flensborg. I London stiftede han bekendtskab med handelslivet og foretog udflugter på landet. Hjemkommet fra denne "grand tour« overtog Johann Gerhard fra 1734 en del af rejseaktiviteterne for brødrene, især hvad angår indkøbene. Han besøgte 
årligt messerne $\mathrm{i}$ Braunschweig og var gennem flere år den 11.juni og 11. december i Danmark. Med varer fra messerne rejste han til Norge. I 1741 opnåede han aftaler om levering af udrustning til 4.800 soldater. Lige indtil 1766 berejste han messerne, først for brødrene, siden som led i sin egen forretnings.

De tre brødre Martin, Friederich og Johann Gerhard drev med andre ord beslægtede forretninger. Det var i 1740'erne de største tekstil- og kramhandeler i Flensborg. De handlede med mange slags lærreder; fine udenlandske fra Wahrendorf, Bielefeld og Schlesien, hjemmevævede hør- og blårlærreder, sejldug og dynevår og drejl, huer og strømper og fynske handsker. Desuden mange slags klæde og uldstof, rask, serge, kamelot, baj, kalemanke, barkan, flonel, chalong, multum, etamin, fries, kinesisk silketøj og bomuldsvarer. Militæret var en stor kunde. Flensborg-grossererne havde leverancer af telte, bluser, skjorter og anden mundering. Endelig var der masser af småting $\mathrm{i}$ forretningerne - bånd, spænder, knapper, lommetørklæder, og hos Martin Feddersen også the, hos Friederich Feddersen hør, vin, landbrugsvarer og mange andre købmandsvarer. De fremmede varer blev købt på messerne i Braunschweig eller ved årsmarkederne i Flensborg, hvor handlende fra Hamborg, Lübeck, Bremen, Westfalen, Altona osv. mødte op med fyldte kramkister. En gang imellem blev varerne importeret direkte fra England eller Holland. De hjemlige varer kom enten fra de lokale fabrikker i Slesvig, Rendsborg, Husum og Glückstadt eller fra håndværkere og husflidsarbejdere $\mathrm{i}$ byen $\mathrm{og}$ på landet. Fra disse lokale producenter fik købmændene bl.a. de betydelige leverancer til militæret. Salget skete i byen og oplandet, til Danmark og Norge og til de mange skibe, som anløb Flensborg ${ }^{6}$.

De tre brødre lod sig imidlertid ikke nøje med tekstilerne. I 1753 overtog Johann Gerhard direktionen for det grønlandske kompagni. Selskabet var oprettet 1749 for at drive handel og hvalfangst på Grønland, Svalbard (Spitzbergen) og Davis Strædet. I 1755 oprettede han og broderen Friederich desuden et »Handlungsgesellschaft auf St.Croix in Westindien«. Også Martin Feddersen fik en part i selskabet og dets skibe. Skibene sendte levnedsmidler, slaveudrustning, byggematerialer m.v. over Atlanten. 1762 udvidedes aktiviteten med anlæggelse af Flensborgs første sukkerraffinaderi i Jørgensby på havnens østside. Familien Feddersen tegnede sig for over halvdelen af anparterne i raffinaderiet $^{7}$.

\section{Den unge købmand}

I dette udprægede forretningsmiljø kom Hans Feddersen til verden i 1739 som søn af Martin Feddersen og Adelheid født Loyt. Moderen var datter af 


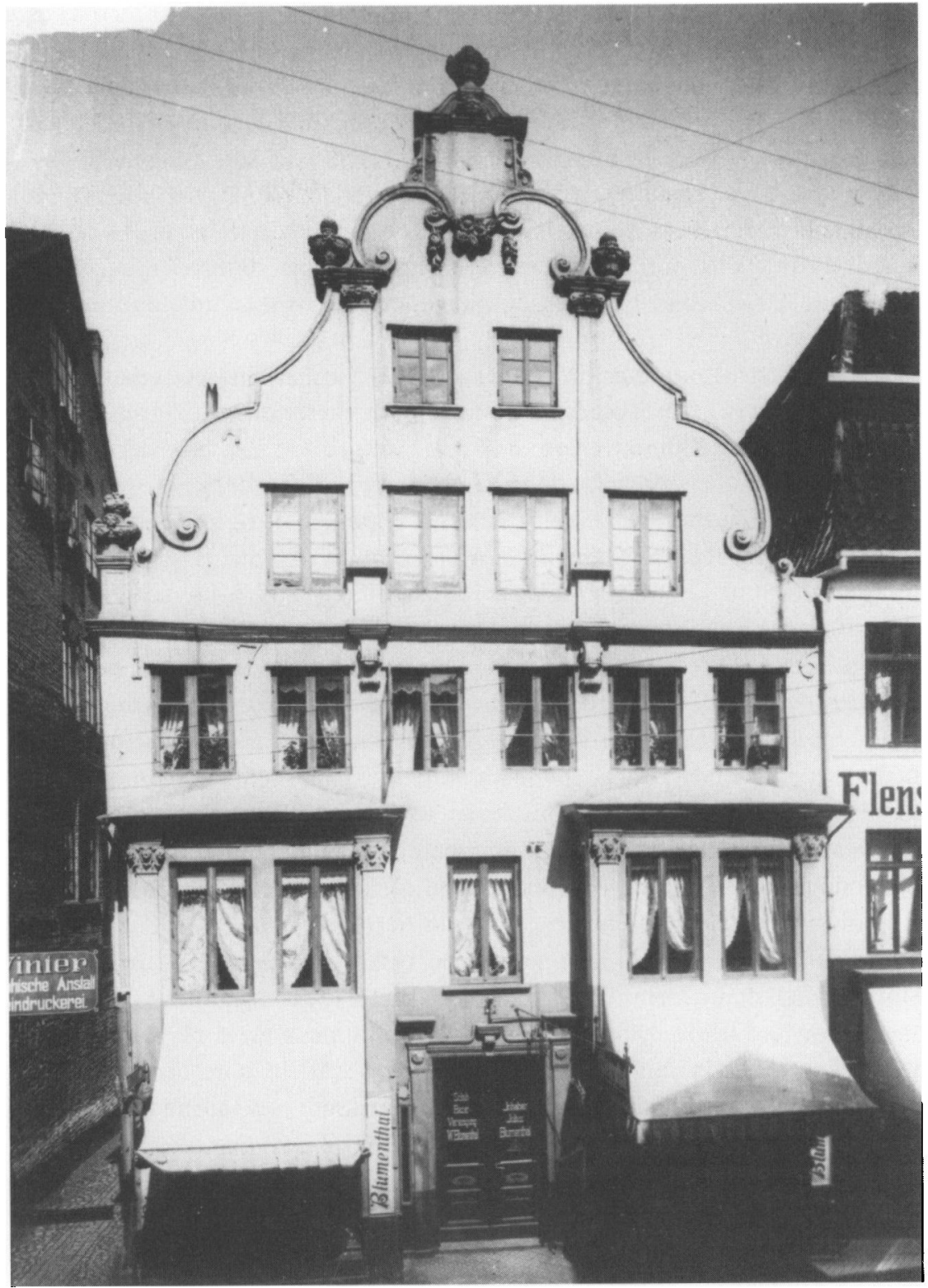

I 1714 kobte Hans Iversen Loyt en statelig ejendom pd Holm $i$ Flensborg - $i$ dag nr.45. Tidligere residerede forst St. Knudsgildet og derpå familien Ahlefeldt fra Søgdrd her. Husets store kaldre gav plads for Loyts omfattende lagre af vin. I 1726 lod vinhandleren arkitekt Chr. Händel ombygge facaden i den senbarokke form, som stort set er bevaret den dag i dag. Foto ca. 1904 i Städtisches Museum. Flensborg. 
borgmester og vinhandler Hans Iversen Loyt (1678-1764). Han var som navnet antyder tilflytter i Flensborg. Faderen var diakon på Løjt, og han havde selv arbejdet sig frem i købmandsverdenen. I Husum, Hamborg og Aabenraa og på mange rejser havde han samlet erfaring og kapital, før han i 1709 slog sig ned i Flensborg som vinhandler. Posten som borgmester $\mathrm{i}$ årene 1748-64 dannede slutstenen i en heldig karriere ${ }^{8}$. Giftermålet i 1737 mellem frk. Loyt og Martin Feddersen skabte forbindelse mellem to velrenommerede firmaer. Handelsbetjenten i Martin Feddersens forretning, præstesønnen Lorentz Jessen fra Bov (1720-98), blev i øvrigt nogle år senere gift med en anden af borgmesterens døtre?.

Ved agteskabet med Martin Feddersen kom Adelheid ind i et velsitueret og anset hjem. I 1743 blev husherren desuden »kommerceassessor «. Den fine titel erhvervede han ved direkte henvendelse til kongen, og han blev derved en af de få rangspersoner $\mathrm{i}$ Flensborg, med forrang forud for byens borgmester og andre rige købmænd ${ }^{10}$. Der kom ti børn i ægteskabet, og der var råd til at sørge godt for dem. Det var ikke svært at give døtrene et pænt udstyr tekstilerne kunne købmanden blot hente i butikken. I 1761 fik datteren Lucia ved giftermål med købmand Rudolf August Cramer i Flensborg (1736-62) således værdier for 5.156 mark 4 skilling. Der var et overdådigt udvalg af tekstiler, deriblandt kostbare udenlandske stoffer: fineste drejl, 1 borddug med 12 damaskes servietter, 31 håndklæder, 19 sengelagner, 5 senge, deraf den bedste seng med edderdunsdyne, 1 himmelseng, $193 / 4$ alen kostbare Brabanter kniplinger og 41 alen mere almindelige kniplinger, 18 manchetskjorter og 6 skjorter uden manchetter, nathuer, lommetørklæder, masser af forskelligt hør-, uld- og silkestof - også 14 alen lærred til to ligskjorter og bryllupsudstyr til henholdsvis to tjenestedrenge og piger var der tænkt på.

Møblerne omfattede bl.a. 26 stole med ryslæder, 4 træstole, 4 lænestole, 1 stort indlagt skab, 2 dragkister, theborde og indskudsborde samt 2 små og 2 store forgyldte spejle. Dertil alskens køkkentøj i messing, kobber, tin, blik og ler. Finere bordservice var der selvfølgelig en del af: 18 porcelænstallerkener, 30 hvide engelske porcelænstallerkener, 18 par kaffe- og 18 par thekopper, 6 par gule thekopper og forskellige skåle og andet bordtilbehør. Endelig var der mere kontante værdier, 200 stk. ducater lig 1.200 mark, 1 guldur til 120 mark, varer fra juveleren for 45 mark 8 skilling samt 6 sølvskeer. Dette fine udstyr blev senere fulgt op af tøj til Lucias børn. Adelheid Feddersen hjalp datteren med en ny dragkiste og en indlagt vugge fyldt med alskens udstyr af lagner, pudevår, kraver, skjorter, huer, bånd og meget andet børnetøj, en del fint udstyret med kniplinger ${ }^{\prime \prime}$.

I alt 10 børn kom som nævnt til verden i ægteskabet, men de 6 døde som små eller $\mathrm{i}$ ung alder. Det har måske været med til at styrke den stærke 


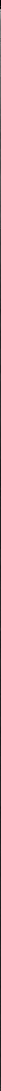

På adressen Holm 7-9 i Flensborg ligger $i$ dag stormagasinet Herties firkantede bygningskompleks. Ejendommens storhedstid ligger imidlertid for indretningen til stormagasin 0.1964. Dengang var der tale om to selvstandige bygninger pd grunden. Her husedes efter 1852 regering og domstole. fra 1883 byens rådhus.

Indtil 1852 var husene domicil for to kabmandsgårde. Set bagfra viste bygningerne de typiske trak $i$ den flensborgske storkobmandsgård forhus og udstrakte rakker af side- og baghuse. I Holm 7 ejendommen til hojre - residerede Martin Feddersen og derefter sonnen Hans $i$ ärene 1737 til 1779. Städtisches Museum, Flensborg, foto o. 1906.

religiøsitet, som Adelheid bragte med fra barndomshjemmet. I den ånd opdrog hun også den ældste søn Hans. Han kom i skole og fik desuden privatundervisning, og det var naturligt, at faderen onskede ham inddraget i forretningen så meget mere som "førstemanden« Lorentz Jessen havde indrettet sin egen manufakturhandel i 1750 samtidig med giftermålet med fru Feddersens søster Maria født Loyt.

Så snart Hans var konfirmeret, blev han derfor sat i lære i familiefirmaet, 
og uddannelsen blev lagt til rette med tanke på, at han en dag skulle overtage forretningen. Martin Feddersen tog sønnen med på de årlige indkøbs- og salgsrejser til messerne i Tyskland og Jylland. Efter nogle år rejste han også alene. Unge Hans blev opdraget som »juniorchef«, og han måtte love at sørge for firmaet til gavn for moderen og de yngre søskende, hvis Martin Feddersen skulle falde $\mathrm{fra}^{12}$. På faderens ældre dage fik han vigtige hverv overdraget. I 1772 påtog han sig f.eks. at varetage sin afdøde morbroder Hans Iversen Loyts forretninger ved Viborg-omslaget" .

To år senere blev det aktuelt at opfylde løfterne. Kommerceassessoren døde, og Hans overtog nu firmaet på sine egne, moderens og de yngre søskendes vegne.

Det kunne synes en ønskestilling. Men i modsatning til onkel Johann Gerhard blev købmandskabet ikke Hans Feddersens »hoved-temperament«. Det var i stedet landlivet, som trak, og det var kun af pligt, han fortsatte $i$ chefstolen. Så snart moderen var død den 11.august 1779, gik han derfor $\mathrm{i}$ gang med at opløse firmaet. Huset på Holm 7 blev solgt til tekstilkøbmand Johann Braack. Varelager og løsøre blev solgt for 15.900 mark. Der blev truffet bestemmelser om de mange mellemværender med kreditorer og debitorer $\mathrm{i}$ hertugdømmerne og det meste af Danmark og Norge, og også skibsparterne blev gradvist afviklet. I sukkerraffinaderiet i Jørgensby beholdt han og broderen Martin foreløbig 1/10 part. En pæn arv blev børnene til del. Til hver af brødrene Hans og Martin Feddersen blev der en lod på knap 18.000 mark $^{13}$.

\section{De vakte i Flensborg}

Hans Feddersen opgav storhandelen "af modvilje mod købmandskabet« - og trods nære slægtninges indstændige råd. Hvorfor? må vi uvilkårligt spørge. Svaret skal nok søges i det åndelige klima i Flensborg. Her herskede på én gang en udpræget materialisme og samtidig en følsom kristendom. Sidst i 1500-årene skrev en rejsende, at alle Flensborg-borgernes gøren og laden kun gik ud på at tjene penge ${ }^{14}$. Holberg beskrev i 1725 flensborgerne som en sparsommelig slægt, ivrig efter at samle, og påholdende med det indsamlede ${ }^{15}$. I Flensborg herskede mere end nogetsteds »esprit de commerce», og luksus havde endnu ikke rigtig fundet indpas, mente Kommercekollegiets udsending Matthias Lunding i $1787^{16}$.

Dette gik imidlertid pænt i spand med både pietismen og senere herrnhuternes tanker, som bl.a. indebar mådehold, uvilje mod verdens fristelser og fornøjelser $\mathrm{og}$ en praktisk indstilling til tilværelsen. Samtidige penne prøvede at vise, at religion og handel ret forstået kunne befrugte hinanden. I 1766 
kunne man læse i Flensburger Adresse Contoirs Nachrichten, at religionen var uundværlig for handelen, i modsætning til hvad man kunne tro i første øjekast. Religionen bød nemlig købmanden at undgå bedrag, at vælge »billige« priser, at være tjenstvillig og venlig, og følgen af en sådan religiøst betinget optræden ville være forøget tillid hos kunderne, større omsætning og gevinst i forretningen! ${ }^{17}$

Et tilsvarende billede af normerne blandt byens velstående købmænd i 1700årene gav præsten Georg Wilhelm Valentiner i 1822 i sin bog »Chronik von Flensburg vom Jahr 1820«: "Af jordiske ting søgte og agtede man kun penge, og dem forstod man at erhverve ved flid og sparsommelighed, begunstiget af lykken. Byens egne unge og de som var sendt hertil, oftest fra landet, blev opdraget til at bede og arbejde; ... Man var barmhjertig og gjorde det gode mod andre. Man agtede kyskhed og var from. Man frygtede Gud og ærede hans bud. Man læste i Bibelen .... ${ }^{18}$.

I de forste årtier af 1700-årene blev pietismen en magtfuld faktor $\mathrm{i}$ byen, og den fandt støtte $i$ nogle af byens rigeste købmandsfamilier. Vajsenhuset fra 1725 - i dag Flensborghus - er bevægelsens synligste resultat ${ }^{19}$.

Siden midten af 1730'erne var der også herrnhutisk vakte kredse i Flensborg, og fra 1755/56 oplevede man næsten en vækkelse. Agtede folk som tobaksfabrikant Johann Valentin Ritter, købmændene Peter Andreas Lorenzen, Jakob Lorenzen, Andreas Lorenzen, Jakob Bischoff, tobaksfabrikant Schmidt og urtekræmmer Franz von der Pahlen blev bevægelsens trofaste hjælpere, og hos Peter Andreas Lorenzen var der $\mathrm{i}$ årene 1763-99 indrettet en regulær forsamlingssal. Fem rejseprædikanter fra Brødremenigheden havde $\mathrm{i}$ disse år bopæl i Flensborg ${ }^{20}$. Herfra betjentes wsocieteterne« i den sydlige del af Slesvig indtil Ekernførde/Kiel, Rendsborg, Frederiksstad og Bredsted, og de berejste Sundeved og Als. I 1789 talte det herrnhutiske samfund i Flensborg 53 voksne og 31 børn $^{21}$.

I dette miljø har Hans Feddersen formentlig som ung modtaget afgørende påvirkninger. Barndomshjemmet har nok også spillet en rolle. Især moderen Adelheid lagde megen vægt på den religiøse opdragelse, og det har sikkert medvirket til at drage sønnen bort fra det ensidige forretningsliv. En anden impuls til at opgive forretningen kom fra en søsters giftermål. Søsteren Maria var gift med Thomas Julius Seyfert von der Merwede på Friedleben i Rodenæs sogn syd for Tønder. Den landlige egn vakte Hans' lyst til landlivet. Så da Kixbølgård i nærheden kom til salg, købte han gården med tilhørende 159 demat jord for $4.900 \mathrm{rdl}$. I 1781 flyttede han ind ${ }^{22}$. På den måde kom Hans Feddersen til en egn, som lige fra begyndelsen af 1700-årene havde givet grobund for først pietismen og senere brødremenighedens vækkelse.

Storkøbmanden var blevet landmand, og nu giftede han sig, med en råd- 
mandsdatter fra Husum. Alvorlige stormfloder i 1792 fik dog Feddersen til at bryde op igen. 1794 flyttede han og konen Margrethe Sophie Carstens til sognefogedgården $\mathrm{i}$ Løjt Kloster. Det var en anselig gård, og prisen var også $6.000 \mathrm{rdl}$. Samtidig solgte han sin andel i sukkerraffinaderiet i Flensborg ${ }^{22}$. Flytningen til Løjt var en tilbagevenden til morfaderen, Hans Iversen Loyts fødesogn. Slægtstilknytningen har nok været med til at fremkalde Hans Feddersens beslutning om at flytte til Løjt. Som landmand tog Feddersen aktivt fat på gårdens drift - man fortalte senere, at han var den første i sognet, som forbedrede jorden ved at strø mergel".

Snart gik hans tanker dog andre veje. I Løjt oplevede han en religiøs krise, som for alvor styrkede forbindelsen til herrnhuterne, og det banede vej for ønsket om endelig at komme helt ud af alle forretninger. 1802 solgte han derfor det meste af Kixbølgård, og gården i Løjt Kloster overdrog han til svigersennen Nis Hohlmann. Feddersen gik på aftægt - en meget rundelig aftægt $\mathrm{i}$ ørigt. Årligt skulle han have 3 tdr. rug, $2 \frac{1}{2}$ tdr. malt, 3 tdr. boghvede, 3 skp. byggryn, 3 skp. byg, 12 pund humle, 2 skp. salt, 2 lispund hør, 6 lispund røget spæk, 6 lispund røget flæsk, 11/2 lispund talg til lys, 5 lispund smør, 2 stige æg, 1 kande sødmælk daglig, 2 får på græs samt deres lam, 24 læs tørv, 1 favn brænde. 3 rdl. i lommepenge, fri vogn til kirke hver anden søndag og ligeledes fri transport til byen 12 gange om året. I haven skulle de nyde udbyttet af 2 æbletræer, desuden kål og grøntsager. Skulle de blive gamle og svage, var svigersønnen forpligtet til at stille dem en pige til rådighed ${ }^{23}$. Hans Feddersen var altså godt sikret, efter landbosamfundets typiske normer. Var han forblevet i Flensborg, ville alderdomsforsørgelsen have formet sig noget anderledes.

Man må imidlertid ikke tro, at Feddersen levede et ganske asketisk liv uden denne verdens nydelser. Fra Andreas Christiansens store sukkerraffinaderi i Flensborg købte han sukker, melis, kandis og sirup, og i anledning af datterens bryllup i 1802 blev der købt godt ind: Hos vinhandler H.I.Loyt i Flensborg 4 flasker gammel rom og et helt anker af den bedste medoc vin. Fra klædehandlerne Hans Cordt Göttig i Flensborg og Andr. Andresen i Aabenraa kom et bredt udvalg af klæde, lærred, bånd, strømper, fiskeben og andet klædningstilbehør ${ }^{24}$.

Da Feddersen havde overladt gården til svigersønnen og havde opgivet de fleste forretninger, kunne han hellige sig de åndelige sysler. Herefter blev han en ivrig støtte for det kirkelige vækkelsesarbejde, med nære kontakter til brødremenigheden. 


\section{Brødremenighedskredse}

I årtierne omkring år 1800 havde brødremenigheden sympatisører blandt ikke så få præster i Sønderjylland og på Fyn. Omkring dem trivedes et levende forsamlingsliv, og udsendinge fra brødremenigheden havde vide kontakter. I Vilstrup samlede Niels Jensen Windekilde og de to sønner Hans Nielsen Windekilde og Jens Peter Nielsen Windekilde fra 0.1780 til 1820 'erne mange - op mod 80 - om møder i præstegården; de holdt bibeltimer og oprettede en bibelforening. Sidstnæunte var først præst i Fjelstrup 1799-1817 og virkede også her i herrnhutisk ånd. I Skærbak kunne pastor Johs. Gjelstrup de første to årtier efter 1800 samle op mod 300 vakte til lignende forsamlinger ${ }^{25}$. På Fyn hørte pastor Jens Frederik Boesen i Vigerslev (1788-1839) og Rasmus Balslev i Hårslev (1789-1840) til samme kreds. År 1800 gjorde de med de tyske bibel- og traktatselskaber som forbillede et fremstød for kirkelig fornyelse og vækkelse. De oprettede »Det danske Selskab til Udbredelse af Evangeliet og sand praktisk Kristendom«, også kaldet »det fynske Selskab til Udbredelse af Evangeliet«. Selskabet var en art præstekonvent med deltagelse af enkelte lægmænd. Det udgav tidsskriftet »Evangelisk Magazin for danske Sandhedselskere« og en lang række større og især mindre religiøse skrifter. Nogle få eksempler er nok til at karakterisere typen: »Børnebibel eller bibelske Sprog med korte Opmuntringer for Børn«, R. Balslevs »Betragtninger over Kristendommen«, K. Knudsens »En fattig Synders Følelser ved Jesu Opstandelse«, R. Balslevs »Opbyggelige Betragtninger for Syge«. Mange af skrifterne kostede blot få skilling. De blev solgt eller uddelt af selskabets medlemmer, gennem kolportører og de herrnhutiske udsendinge. Enkelte blev også oversat til tysk, og især toldkontrollør H.W. Hansen i Slesvig var flittig til at udbrede de tyske oversættelser. Selskabet fik hurtigt sit tyngedepunkt i Sønderjylland, hvor en række lægmænd sluttede sig til præstemedlemmerne ${ }^{26}$. Den rige borgmester Carsten Richtsen i Tønder støttede hvert år kassen med 150 rdl., og mindre bidrag kom fra bl.a. Johannes Boisen i Tønder, rådmand Vieth og guldsmed Johann Adolph Møller i Haderslev og fabrikant V.Ritter i Flensborg ${ }^{27}$.

\section{Feddersen og vækkelsesarbejdet}

Også Løjt sogn og Hans Feddersen kom med i arbejdet, og nogle breve i Feddersens arkiv gør det muligt at kaste lidt lys over livet $i$ de vakte kredse ${ }^{28}$. Det var især efter 1802, at der kom gang i arbejdet. Løjt søgte dette år en ny diakon. Pastor Andreas Matthiesen på Nordmarsch var kandidat - og Hans Feddersen var med til at bane vejen. Da valget var truffet, takkede Matthiesen 


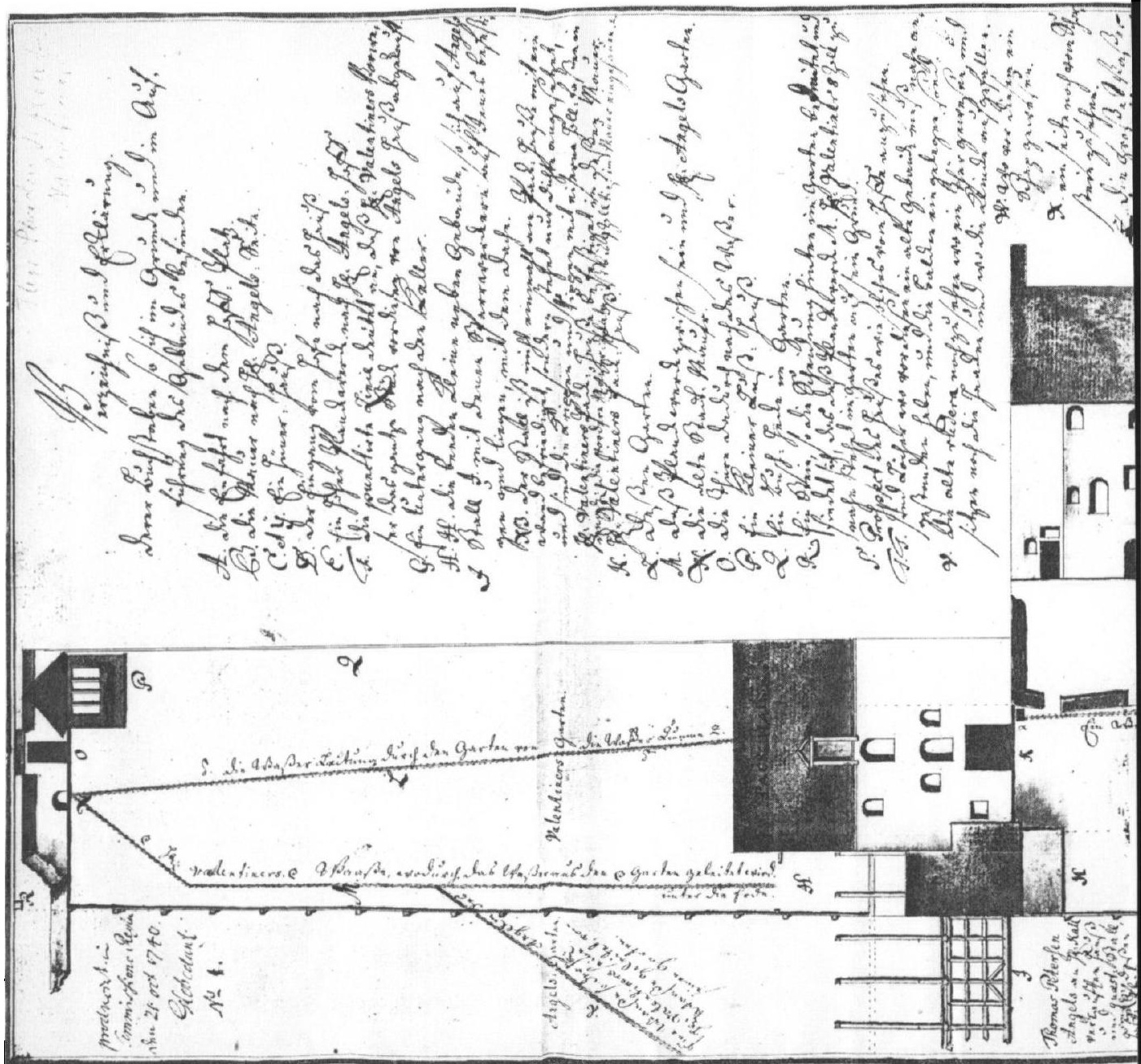

På den ostlige side af Holm boede Flenshorgs fornemste købmand. En af de rigeste i 1700-arene var Wilhelm Valentiner (d.1749). I 1739 blev der udarbejdet en tegning af Valentiners ejendom set $i$ tvarsnit, i dag Holm nr. l. Den giver et fint indtryk af en stor kebmandsgärds typiske indretning. Ud mod gaden (til hojre) lå forhuset med forretning og boligrum. I det forste sidehus $i$ gården là de reprasentative rum - salen med fornemme dore, paneler, stukudsmykning osv. I naste sidehus var der bl.a. sovekamre. Bagest $i$ gården lå pakhuset, men naturligvis var der også plads til varer pả de andre huses lofter.

Til venstre ses haven med lysthus og muren ned mod havnen.

Tegning $i$ Stadtarchiv Flensburg XII Hs $960^{2}$. 


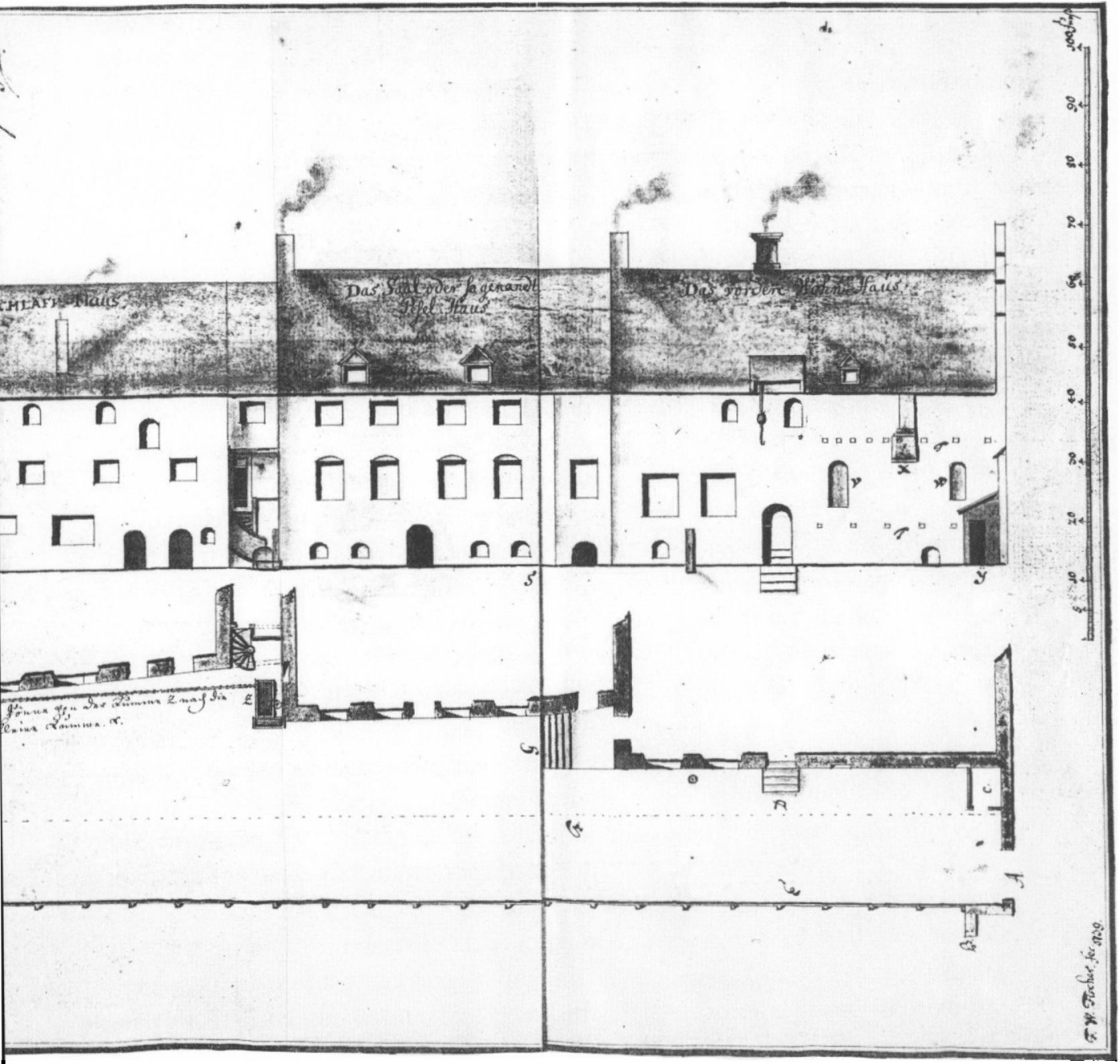

den 1.marts 1802 ægteparret Feddersen for venskab og kærlighed og bad om, at de ville foranstalte den nye præsts traditionelle introduktionsmåltid.

I de følgende år skabte Matthiesen et levende menighedsliv i Løjt. Han og søsteren holdt møder i præstegården, stiftede en herrnhutisk kreds og en bibelforening og vakte interesse for hedningemissionen, alt $i$ kontakt med proherrnhutiske kredse $\mathrm{i}$ resten af Sønderjylland og på Fyn. "Det fynske selskab« fandt en god støtte i Matthiesen, og i selskabets regnskabsprotokol dukker herefter også Feddersen og andre gode Løjtinger op blandt bidragyder- 
ne, således Marcus Schmidt, Jesper Petersen og Jesper Eschelsen ${ }^{27}$. Hos egnens rationalistiske præster, især provst Peter Paulsen i Aabenraa, var Matthiesen mindre populær.

Familien Feddersen deltog ivrigt $\mathrm{i}$ arbejdet som Matthiesens nære venner. Den 11.april 1806 var Feddersen til et af de mange aftenmøder i præstegården og hørte, at der fra Store Vi i Sydslesvig var bud efter den populære præst. Feddersen gik bekymret hjem, og den følgende morgen skrev han til Matthiesen for at holde ham tilbage bl.a.: "De er nu en gang sat her af Herren for at drive hans værk ... Herren giver $\mathrm{i}$ særlig grad nåde, kraft og Helligåndens bistand til Dem ... Ak, hvor mange sjæle - mange kendte, endnu flere ukendte - er ikke grebet deraf, hvor mange planter er ikke derved plantet i nåde på Herrens vinbjerg; de har brug for daglig pleje og opsyn for at kunne vokse $i$ Guds nåde og i erkendelsen af Jesus Kristus. Vel må den himmelske vingårdsmand selv gøre det bedste, men han benytter også tjenere og lærere, som han sender ud og udruster for at lægge menneskene det dyrebare evangelium på hjerte og for at så det guddommelige ords sæd. Ak, hvis nu en sådan lærer og arbejder på Herrens vinbjerg rejser bort, så kan de sarte planter let visne igen ..... Matthiesen burde også betænke, at »en sand evangelisk lærer er sjælden, især i denne egn « ... "hele kleresiet ville glæde sig og gøre Herrens værk til spot. Ak, måtte den kære frelser forbarme sig, og lade sit dyrebare ord blive hos os«.

Brevet gjorde sin virkning, og brødremenigheden bevarede en fast støtte $\mathrm{i}$ Løjt. I 1812 blev Matthiesen endda forfremmet til sognepræst.

Feddersens breve gør det også muligt at følge arbejdet i det fynsk-slesvigske selskab til evangeliets udbredelse. Han korresponderede med flere af selskabets medlemmer, bl.a. de to præstebrødre Windekilde i Vilstrup og Fjelstrup. Den 15. marts 1803 takker pastor Hans Windekilde i Vilstrup for tilsendte beger og glæder sig over de engelske og tyske missionsselskabers og brødremenighedens arbejde. Et lard skrift om den kristne religions sandhed og en beretning fra det engelske missionsselskab blev Feddersen bedt om at lade gå videre til Matthiesen.

Feddersen hjalp også med den gratis udbredelse af det fynsk-slesvigske selskabs publikationer. I 1806 sendte han en bunke småskrifter til pastor Andreas Thomsen i Sørup, og med den flittigste fordeler af skrifterne toldkontrollør H.W. Hansen i Slesvig - stod han i nær kontakt. Selskabet holdt hvert år generalforsamling hos et af medlemmerne, f.eks. i Skærbæk hos pastor Johs. Gjelstrup eller i Fjelstrup hos Jens Windekilde, og der blev udvekslet referater fra forsamlingerne.

Med årene tog Feddersens kræfter af, og han måtte melde afbud til en del af selskabets møder. Datteren døde i 1807, trøstet ved læsning af Balslevs 
"Opbyggelige Betragtninger for Syge«. Hans egen aktionsradius blev mere og mere begrænset. Han fortsatte brevkontakten med "selskabet til evangeliets udbredelse " og udvekslede mødereferater med vennerne. I stigende grad samlede tankerne sig om sjælens frelse, indtil han endelig den 8.oktober 1813 nåede sit mål.

Et levnedsløb var slut - og det må kaldes lidt usædvanligt. Feddersen voksede op i storbyen Flensborgs handelselite, og selv ledede han indtil sit 41. år et af byens store handelsfirmaer. Lysten til denne branche var dog ikke stor, og så vidt vi kan se, blev han påvirket af den brødremenighedsmission, som dengang vandt bred genklang i Flensborgs købmandsmiljø. Om de nærmere omstændigheder ved vi imidlertid i dag ikke meget. Kilderne i brødrearkivet i Herrnhut og delvis i Christiansfeld er ikke tilstrækkeligt udforsket. Men det står klart, at Feddersen opgav handelen - han blev landmand, og efter nogle år kappede han de sidste bånd til forretningsverdenen. I stedet blev han deltager i det proherrnhutiske missionsarbejde. Han deltog ivrigt i pastor Matthiesens forsamlinger i Løjt, korresponderede med medlemmerne af »Det danske Selskab til Udbredelse af Evangeliet og sand praktisk Kristendom« og var med til at udbrede selskabets skrifter.

Landmanden J. Thaysen i Mettenwarf i Rodenæs sogn, som forvaltede Feddersens ejendom i Kixbøl efter flytningen til Løjt, skrev i 1809 til sin gamle ven: "Du lever $\mathrm{i}$ din alderdom roligt og tilfreds og har som en kristen overstået de storme, som du mødte på din livsbane, fordi dyd og religion er dine tro vejvisere ${ }^{29}$. Dette er vist en ganske rammende karakteristik af Feddersens biografi. Sådan gik ånd og materie til slut op i en højere enhed hos et barn af det mammon-dyrkende Flensborg.

\section{NOTER OG HENVISNINGER}

1. LA Åb Løjt sogns kirkebog Ab 2.

2. Chr. Kiilsgaard: Rudkøbing. Topografi og bystyre bd. 2, 1955 s. 15, 71, 90, 266 og 289; bd. 3, 1970 s. 133.

O. H. Moller: Genealogische Tabellen von ... Peter Feddersen u. ... Lucia Süling. Flensburg 1774.

3. Personalia des Herrn Peter Feddersen, manus. i LA Åb E.Juhlers privatarkiv 371/IX.

Aage Bonde og Johan Hvidtfeldt: Borgmestre, rådmænd, byfogeder og byskrivere i Flensborg $1550-1848,1961 \mathrm{nr} .135$ og 139.

4. Oplysninger om husenes ejerforhold i Flensborg byarkiv XII Hs 1091 Bd. 18.

5. Flensborg byarkiv A 222. - Uddrag af selvbiografien i Das Flensburger Schiffergelag in Vergangenheit und Gegenwart, 1979 s. $75 f$.

6. RA Kommercekollegiet, tyske sekretariat 355. (1748). Flensborg byarkiv A 307 Bd. 1 (kræmmerlister 1774ff).

7. Theodor Link: Flensburgs Überseehandel von 1755 bis 1807 (1959). 
8. E.Juhler: Præstesønnen fra Løjt der blev borgmester i Flensborg (SJy MSkr 1935-36 s. 198-201). - H.I.Loyts ligtale i LA Åb E. Juhlers privatarkiv 371/IX. - O. H. Moller: Genealogische Tabelle von Hans Iversen Loyt. Flensburg 1769. Flensborg byarkiv XII Hs. 651a, 17.

9. LASH Abt. 167 AR Flensburg 1746 II bilag 93 og 94 (formue- og næringsskat 1744). - Flensborg byarkiv A 307 Bd. 1 (kræmmerlister). - Aage Bonde og Johan Hvidtfeldt: Borgmestre, rådmænd, byfogeder og byskrivere i Flensborg 1550-1848, $1961 \mathrm{nr} .165$.

10. Dieter Pust: Politische Sozialgeschichte der Stadt Flensburg, 1975, s. 57-61.

11. Privateje, jvfr. E.Juhlers privatarkiv 371/IX.

12. Hans Feddersens biografi i LA A b E. Juhlers privatarkiv 371/IX.

13. Skifteakter i LA Ab E. Juhlers privatarkiv 371/IX.

14. Flensborg bys historie 1,1953 s. 193.

15. Flensburg. Geschichte einer Grenzstadt, 1966 s. 171.

16. Matthias Lundings rejsedagbog 1787, Kulturminder 3. rk. bd. 2, 1979 s. 54.

17. Flensburger Adresse Contoirs Nachrichten 1767 30. september.

18. G.W.Valentiner: Chronik von Flensburg vom Jahr 1820 . Altona $1822 \mathrm{~s} .191 \mathrm{f}$.

19. H.F.Petersen: Der Pietismus in Flensburg. Aus Flensburgs Geschichte, 1963 s. 7-37.

20. J. Brodersen: Fra gamle dage, 1912 s. 486-507.

21. Brødremenighedens arkiv i Christiansfeld P.A.I.R.1.A.5 e, synodeberetning 1789, jvfr. Vakkelsernes Frembrud i Danmark i forste halvdel af det 19. Århundrede IV, 1967 s. 135.

22. som note 12 .

23. LA Åb Retsbetjentarkiver Aabenraa amts bibog nr. 994 s. 658-661.

24. LA Åb E.Juhlers privatarkiv 371/IX regninger til Hans Feddersen.

25. A.Pontoppidan Thyssen: Dansk præste- og sognehistorie X Haderslev stift, 1977 s. 143 f.

Paul Nedergaard: En dansk præste- og sognehistorie. Sønderjylland I 1972 s. 223.

26. Vakkelsernes Frembrud i Danmark i første Halvdel af det 19. Århundrede III 1, 1964 s. 50-53. Anders Pontoppidan Thyssen: Vækkelse, kirkefornyelse og nationalitetskamp i Sønderjylland 1815-1850, 1977 s. 62 f.

27. Brødremenighedens arkiv i Christiansfeld P.A.II.R.14.2 a.

28. LA Åb E.Juhlers privatarkiv 371/IX. Alle breve er på tysk, her oversat.

29. Her oversat. Privateje, jvfr. note 11. 